\title{
触 New Disease Reports \\ First report of Potato yellow mosaic virus infecting Solanum americanum in Venezuela
}

\author{
G. Romay ${ }^{1}$, D.T. Chirinos ${ }^{2,3}$, F. Geraud-Pouey ${ }^{2,3}$, M. Torres ${ }^{4}$ and C. Bragard ${ }^{1 *}$
}

${ }^{1}$ Université catholique de Louvain, Earth and Life Institute, Applied Microbiology-Phytopathology, Croix du Sud 2 Bte L07.05.03, 1348 Louvain-la-Neuve, Belgium; ${ }^{2}$ Laboratorio de Entomología, Facultad de Ciencias Agrarias, Universidad Agraria del Ecuador; ${ }^{3}$ La Universidad del Zulia, Facultad de Agronomía, Unidad Técnica Fitosanitaria, Maracaibo 4005, Venezuela; ${ }^{4}$ Departamento de Biología Celular, Universidad Simón Bolívar, Carretera Nacional Hoyo de la Puerta, Sartenejas, Caracas 1080, Venezuela

*E-mail: claude.bragard@uclouvain.be

Received: 28 Jun 2016. Published: 24 Oct 2016. Keywords: begomovirus, emerging virus, potential virus sources, solanaceous weeds

Potato yellow mosaic virus (PYMV) is one of the most important tomato begomoviruses in the Caribbean basin (Morales et al., 2006). In Venezuela, a recent survey showed that PYMV is the most widespread and prevalent begomovirus in tomato fields (Geraud-Pouey et al., 2016). However, little is known about natural reservoirs of the virus. In 2007 and 2008 PYMV surveys were performed in several Venezuelan tomato fields and weeds in the genus Solanum showing virus-like symptoms were also collected (Fig. 1). As summarised in Table 1, nine leaf samples from solanaceous weeds were tested using PCR with PYMV-specific primers (Geraud-Pouey et al., 2016). PYMV infection was detected in two plants each of Solanum americanum and S. pimpinellifolium. Solanum pimpinellifolium is considered a host of PYMV (Boissot et al., 2008). However, S. americanum has not been found previously to be infected by this begomovirus. Hence, the complete sequence of DNA-A of PYMV isolates from the two $S$ americanum plants (herafter, Tachira-949 and Lara-1203) were obtained by rolling circle-amplification (RCA) using $\$ 29$ DNA polymerase (TempliPh kit, GE Healthcare, Germany). The RCA products were then digested with the endonuclease HindIII and inserted in pBluescript II (SK+) for cloning The complete sequences of DNA-A of isolates Tachira-949 (2,597 bp) and Lara-1203 (2,596 bp) were deposited in GenBank under Accession Nos. KU665804 and KX389269, respectively. Blast analyses revealed that PYMV isolate (D00940) from Venezuela was the most closely related isolate to the isolates Tachira-949 and Lara-1203 showing 94 and 93\% nucleotide identity, respectively. PYMV-like sequences in GenBank were retrieved to perform pairwise and phylogenetic analyses using Mega 6 (Tamura et al., 2013). Isolates Tachira-949 and Lara-1203 shared 96\% nucleotide identity and they were most related phylogenetically to PYMV isolates from Central America and Venezuela (Fig. 2). Interestingly, the two PYMV-infected $S$. americanum plants were found in geographically distant tomato production zones of the country.

Begomoviruses are transmitted by Bemisia tabaci which is considered a cryptic species complex. Within this complex, the polyphagous whitefly referred as Middle East Asia-Minor 1 is widespread in Venezuela (Romay
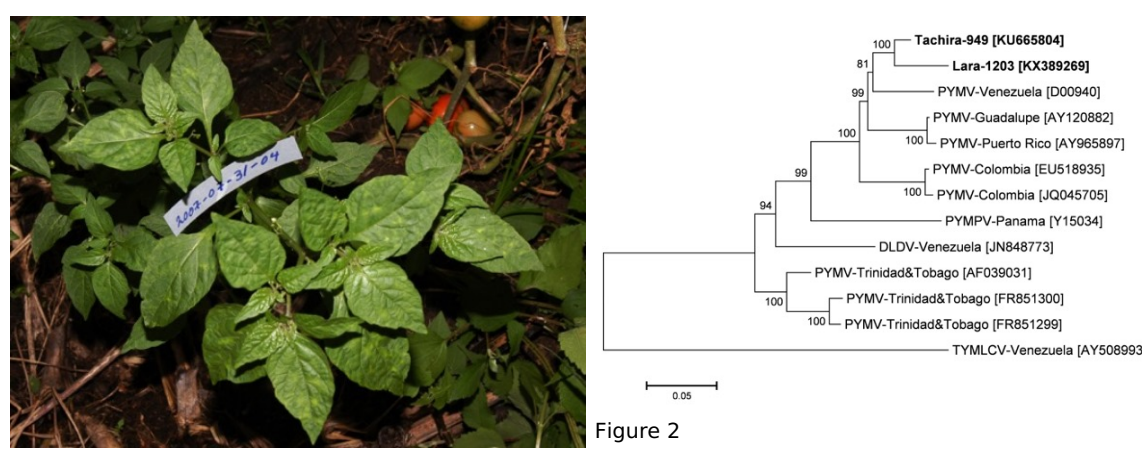

et al., 2011) and its contribution to increasing the number of natural reservoirs may be speculated. Although our results suggest that $S$. americanum might be a natural host for PYMV, more extensive surveys are needed to confirm whether this weed is an important alternative host in the field.

\section{Acknowledgements}

This research was partly funded by the Venezuelan Ministry of Higher Education, Science and Technology award number FONACITG-2000001610. Gustavo Romay was supported by a Move-In Louvain fellowship from the Université catholique de Louvain.

\section{References}

Boissot N, Urbino C, Dintinger J, Pavis C, 2008. Vector and graft inoculations of Potato yellow mosaic virus reveal recessive resistance in Solanum pimpinellifolium. Annals of Applied Biology 152, 263-269. http://dx.doi.org/10.1111/j.1744-7348.2007.00213.x

Geraud-Pouey, Chirinos DT, Galindo-Castro I, Franco MA, Santana MA, Gillis A, Romay G, 2016. Occurrence of six begomoviruses infecting tomato fields in Venezuela and genetic characterization of Potato yellow mosaic virus isolates. Journal of Phytopathology 164, 697-703. http://dx.doi.org/10.1111/jph.12445

Morales FJ, 2006. History and current distribution of begomoviruses in Latin America. Advances in Virus Research 67, 127-162. http://dx.doi.org/10.1016/S0065-3527(06)67004-8

Romay G, Geraud-Pouey F, Chirinos DT, Santana MA, Galindo-Castro I, Márquez LM, 2011. Microsatellites reveal widespread predominance of an invasive over an indigenous Bemisia tabaci in Venezuela.

Phytoparasitica 39, 419-428. http://dx.doi.org/10.1007/s12600-011-0175-3

Tamura K, Stecher G, Peterson D, Filipski A, Kumar S, 2013. MEGA6:

Molecular Evolutionary Genetics Analysis Version 6.0. Molecular Biology and Evolution 30, 2725-2729. http://dx.doi.org/10.1093/molbev/mst197

Figure 1

To cite this report: Romay G, Chirinos DT, Geraud-Pouey F, Torres M, Bragard C, 2016. First report of Potato yellow mosaic virus infecting Solanum americanum in Venezuela. New Disease Reports 34, 20. http://dx.doi.org/10.5197/j.2044-0588.2016.034.020 (c) 2016 The Authors

This report was published on-line at www.ndrs.org.uk where high quality versions of the figures can be found. 